\title{
Air quality study for Montenegro Pljevlja area
}

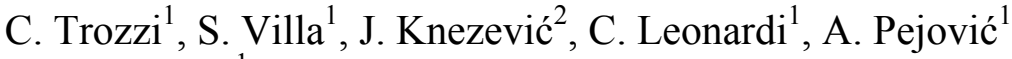 \\ \& R. Vaccaro ${ }^{1}$ \\ ${ }^{1}$ Techne Consulting srl, Rome, Italy \\ ${ }^{2}$ Ministry of Sustainable Development and Tourism of Montenegro, \\ Montenegro
}

\begin{abstract}
The paper reports the air quality study for Montenegro, Pljevlja area, developed in the frame of technical assistance to the Montenegrin Ministry of Sustainable Development and Tourism and Environmental Protection Agency on all activities related to air quality management.
\end{abstract}

Keywords: emissions inventory, emissions projections, air quality models, CALPUFF model, air quality management plan, coal mine, district heating.

\section{Introduction}

According to the National Law on Environmental Protection, Montenegro has recently produced the National Air Quality Strategy in order to reduce air pollution and its possible negative impacts on human health and environment. The Strategy is aimed to pursue an improvement of air quality in the whole Country during the following four years and covers many different sectors, such as ambient air quality, industrial pollution control, climate change, acidification and eutrophication, long range transboundary pollution and ozone depleting substances. The Ministry of Sustainable Development and Tourism of Montenegro established to start implementing the Strategy drafting the first Air Quality Plan related to the Municipality of Pljevlja. The paper reports the preparatory technical studies for the preparation of Pljevlja Air Quality Plan.

\section{Main sources of pollution}

In order to determine the main sources of pollution in the area of Pljevlja and understand which are the sectors mainly contributing to local air pollution, a 
local air emissions inventory was produced. The local inventory contains emissions coming from point, line and area sources and related to the different activities that can produce air pollution, according to EMEP/EEA SNAP nomenclature. Starting from the national inventory compiled for Montenegro and related to 2010, additional data and information were collected to make a deeper analysis of local situation and increase the knowledge of the territory.

The local air emissions inventory for the Municipality of Pljevlja was compiled in two steps: first of all the emissions inventory previously produced for Montenegro at national level was disaggregated at local level using all available data describing the emission sources in each Municipality. Where direct parameters related to Municipalities were not available, proxy variables were used. Proxy variables are parameters used to estimate the distribution over the territory of activities responsible of air emissions; they are general data such as population, employees in different sectors, agricultural land.

In order to make a deeper analysis of the contribution of different emission sources to the levels of pollution in the area, additional data were collected from the thermo power plant, the coal mine and the Municipality of Pljevlja. The inventory was therefore integrated with an additional point source of emissions, the boiler used as a district heating system serving 492 users, with diffuse emissions from the open coal mine (particulate matter coming from erosion and transport systems) not estimated before, and with more detailed information on fuel consumptions for heating in domestic and service sectors.

An estimation model was developed for the coal mine to take into account emissions coming from handling of solid materials and its transport in the coal mine area. All available information on amount of handled material, characteristics of coal, meteorological data on wind and precipitations, handling and transport systems were used to calculate specific emission factors to obtain average dust emissions in the area. The implemented methodology is coherent to the international one, suggested by the new version of the EMEP/EEA Air pollutant emission inventory guidebook [1] and derived from US EPA AP42 [2].

Table 1: $\quad$ Emissions of $\mathrm{NO}_{\mathrm{x}}, \mathrm{PM}_{10}, \mathrm{PM}_{2.5}, \mathrm{SO}_{\mathrm{x}}$ and $\mathrm{B}[\mathrm{a}] \mathrm{P}$, Pljevlja 2010.

\begin{tabular}{lrrrrr}
\hline Macrosector & \multicolumn{5}{c}{ Emissions } \\
\hline & $\begin{array}{r}\mathrm{NO}_{\mathrm{x}} \\
(\mathrm{Mg})\end{array}$ & $\begin{array}{r}\mathrm{PM}_{10} \\
(\mathrm{Mg})\end{array}$ & $\begin{array}{r}\mathrm{PM}_{2.5} \\
(\mathrm{Mg})\end{array}$ & $\begin{array}{r}\mathrm{SO}_{\mathrm{x}} \\
(\mathrm{Mg})\end{array}$ & $\begin{array}{r}\mathrm{B}[\mathrm{a}] \mathrm{P} \\
(\mathrm{kg})\end{array}$ \\
\hline 01 - Comb. in energy and transf. ind. & 4131.06 & 701.82 & 201.41 & 25742.07 & 1.19 \\
02 - Non-industrial combustion plants & 46.63 & 17.97 & 16.66 & 202.59 & 3.20 \\
03 - Combustion in manufact. Industry & 3.98 & 23.47 & 6.84 & 23.92 & 0.56 \\
04 - Production processes & 0.00 & 103.58 & 25.06 & 0.00 & 0.00 \\
05 - Extract. and distrib. of fossil fuels & 0.00 & 799.94 & 128.39 & 0.00 & 0.00 \\
06 - Solvent and other product use & 0.00 & 0.00 & 0.00 & 0.00 & 0.00 \\
07 - Road transport & 150.59 & 11.62 & 10.09 & 1.32 & 0.07 \\
08 - Other mobile sources and machin. & 44.59 & 2.25 & 2.25 & 4.82 & 0.04 \\
09 - Waste treatment and disposal & 0.00 & 0.00 & 0.00 & 0.00 & 0.00 \\
10 - Agriculture & 0.05 & 159.92 & 18.76 & 0.01 & 0.18 \\
11 - Other sources and sinks & 1.24 & 155.06 & 139.56 & 0.00 & 28.11 \\
\hline Total emissions & $\mathbf{4 3 7 8 . 1 5}$ & $\mathbf{1 9 7 5 . 6 4}$ & $\mathbf{5 4 9 . 0 1}$ & $\mathbf{2 5 9 7 4 . 7 2}$ & $\mathbf{3 3 . 3 5}$ \\
\hline
\end{tabular}


As a result of the activities described in the previous paragraphs the local air emissions inventory for the Municipality of Pljevlja was compiled. shows total emissions of relevant air pollutants, that are nitrogen oxides $\left(\mathrm{NO}_{\mathrm{x}}\right)$, particulate matter with diameter less than $10 \mu \mathrm{m}\left(\mathrm{PM}_{10}\right)$ and less than $2.5 \mu \mathrm{m}\left(\mathrm{PM}_{2.5}\right)$, sulphur oxides $\left(\mathrm{SO}_{\mathrm{x}}\right)$. Since the air quality monitoring network registered also quite high concentrations of benzo(a)pyrene, $(\mathrm{B}[\mathrm{a}] \mathrm{P})$, emissions estimated for this pollutant are reported.

As expected, main contribution to local air emissions comes from combustion activities (mainly the boiler of the thermo power plant, road transport and non industrial combustion plants for heating in domestic and services sectors) and processes related to extraction, handling and transport of solid fuels (the coal mine). The highest contribution is, as expected, associated to the thermal power plant: $94 \%$ of $\mathrm{NO}_{\mathrm{x}}, 99 \%$ of $\mathrm{SO}_{\mathrm{x}}, 36 \%$ of $\mathrm{PM}_{10}$ and $37 \%$ of $\mathrm{PM}_{2.5}$. It must be underlined that in terms of impact of the emission sources of air pollution in the Municipality the falling down of thermal power plant emissions has to be investigated. Agricultural activities are diffuse sources of pollution, spread over the territory of the entire Municipality. Even if quite high PM emissions come from these activities it has to be underlined that they are not concentrated in the surrounding of the urban area, as it happens for other relevant activities (thermal power plant, coal mine, road transport and domestic heating). Emissions are distributed over the total surface covered by agricultural land (68442 ha). That means, for instance, only $0.002 \mathrm{Mg} / \mathrm{ha}$ of $\mathrm{PM}_{10}$ emissions from macrosector 10 .

As shown in table 1, main source of benzo(a)pyrene emissions is the eleventh macrosector, mainly due to the activity forest fires. Emissions from fires are subject to a great variability, being unpredictable events whose extension and impact change year by year.

The impact of thermal power plant emissions on the urban area of Pljevlja was estimated through the application of CALPUFF model [3] in a previous study [4]. Due to the high chimney $(250 \mathrm{~m})$ of the plant, emissions have a quite large area of dispersion; they pass over the urban area of Pljevlja and fall down far from it. The maps describing dispersion of plum and levels of $\mathrm{NO}_{\mathrm{x}}$ and $\mathrm{PM}_{10}$ from the thermal power plant are shown in the following figure.
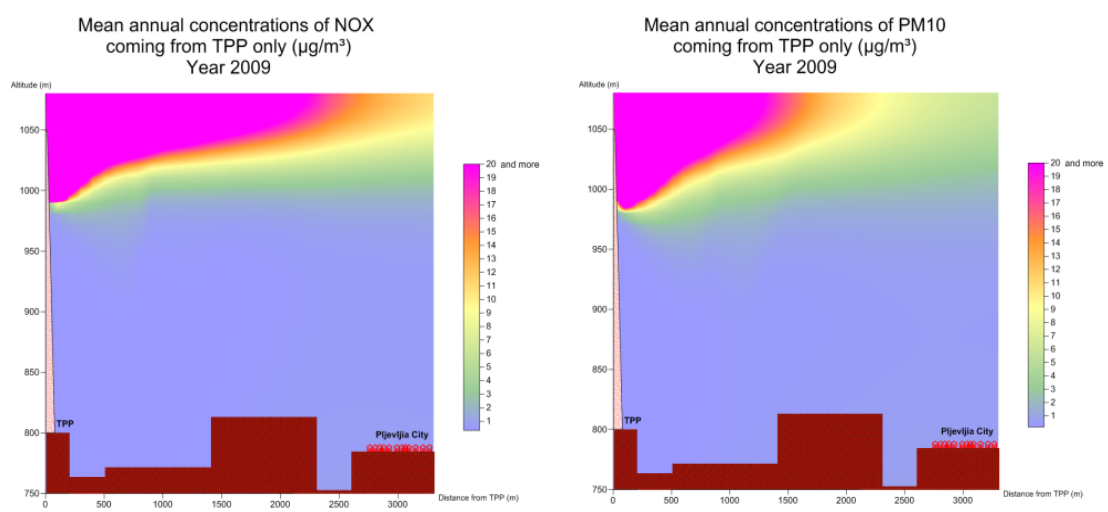

Figure 1: $\quad \mathrm{NO}_{\mathrm{x}}$ and $\mathrm{PM}_{10}$ levels due to thermal power plant, 2009. 


\section{Air quality modeling}

The air quality modelling system CALPUFF [3] was used to analyse dispersion and transformation of pollutants over the territory of the Municipality of Pljevlja. Particularly, deposition and concentration of nitrogen dioxide $\left(\mathrm{NO}_{2}\right)$, sulphur dioxide $\left(\mathrm{SO}_{2}\right)$ and particulate matter with diameter up to $10 \mu \mathrm{m}\left(\mathrm{PM}_{10}\right)$ and up to $2.5 \mu \mathrm{m}\left(\mathrm{PM}_{2.5}\right)$ were evaluated.

The modelling activity was carried out through the following steps:

- Disaggregation of 2010 emissions by activities (the more detailed level) on grids of $1 \mathrm{~km} \mathrm{x} 1 \mathrm{~km}$ and allocation of emissions. Results coming from the new 2006 CORINE Land Cover Project were used;

- Temporal disaggregation of 2010 emission on an hourly basis using variables about the monthly, daily and hourly activities distribution

- Emission extraction from inventory on each grid and each hour of the year

- Application of meteorological models MM5 V3 [5], designed to simulate or predict mesoscale and regional-scale atmospheric circulation, and CALMET [6] to simulate atmospheric conditions as well as land use data

- Application of the lagrangian puff dispersion model CALPUFF in order to obtain results on the dispersion of pollutants over the territory

- Comparison of model results with the legislative limit values to check compliance and evaluate the effectiveness of plan measures.

Meteorological data needed as input data for MM5 and CALMET were obtained from the following sources: geomorphologic input, surface and upper air observations for MM5 from NCAR website; geomorphologic input for CALMET from the European CORINE Land Cover project (related to year 2000); surface meteorological data from Hidrometeorološki Zavod (Hydrological and Meteorological Service of Montenegro), weather station of Pljevlja.

The geographical domain of application was chosen as a square $30 \times 30 \mathrm{~km}$ wide, with the Thermo power plant (TPP) in the centre of it and a grid of $1 \times 1 \mathrm{~km}$ cells. After successful calibration, the model results in terms of hourly concentrations over every single cell of geographical domain and every hour of the year have been elaborated in order to produce maps for the considered pollutants.

Annual mean concentrations of sulphur dioxide, nitrogen dioxide and particulate matter $\left(\mathrm{PM}_{10}\right.$ and $\left.\mathrm{PM}_{2.5}\right)$ as estimated through the application of CALPUFF model, are shown in Figure 2. Each map represents the distribution of mean annual concentration of pollutants over the territory of Pljevlja and reports the overall maximum registered concentrations. The location of thermo power plant and the outline of urban area are also indicated.

As it appears from the maps, only $\mathrm{PM}_{10}$ concentrations exceed the limit values in the surroundings of the urban area. Figure 3 shows the area where the daily limit value established for $\mathrm{PM}_{10}$ exceeds more than the allowed 35 times. The model therefore confirms the results obtained by the monitoring network regarding exceedances of the limit values for $\mathrm{PM}_{10}$; the adoption of an air quality plan and the implementation of reduction measures are therefore necessary in order to reduce local air concentrations of this pollutant. 


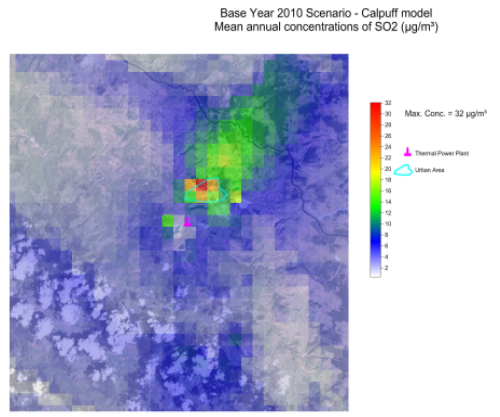

Base Year 2010 Scenario - Calpuff model
Mean annual concentrations of NO2 $\left(\mathrm{ug}^{2} \mathrm{~m}^{3}\right)$

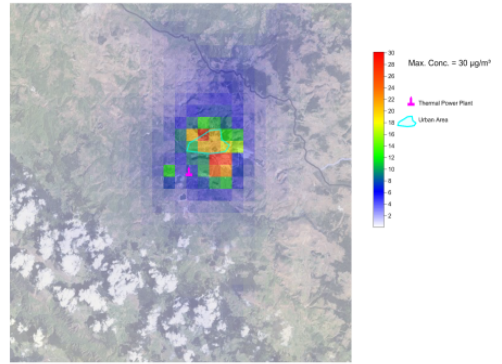

Base Year 2010 Scenario - Calpuff model
Mean annual concentrations of PM2.5 ( $\left.\mu g / \mathrm{m}^{3}\right)$

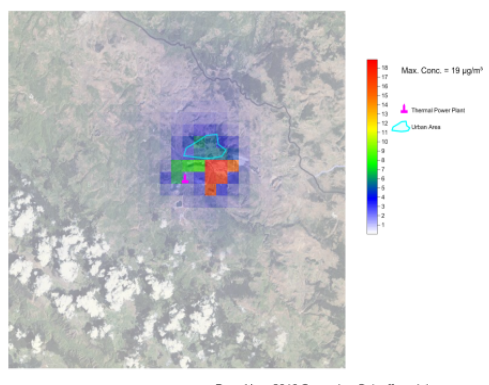

Base Year 2010 Scenario - Calpuff model
Mean annual concentrations of PM10 $\left(\mu \mathrm{g} / \mathrm{m}^{2}\right)$

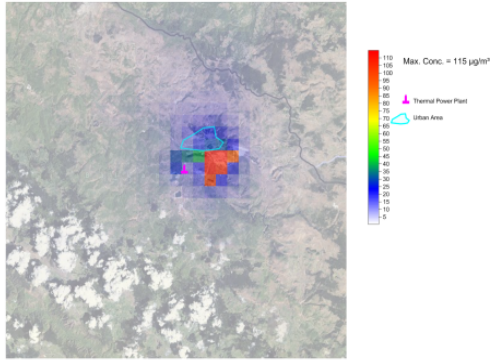

Figure 2: $\quad$ Annual average concentration of pollutants over Pljevlja, 2010.

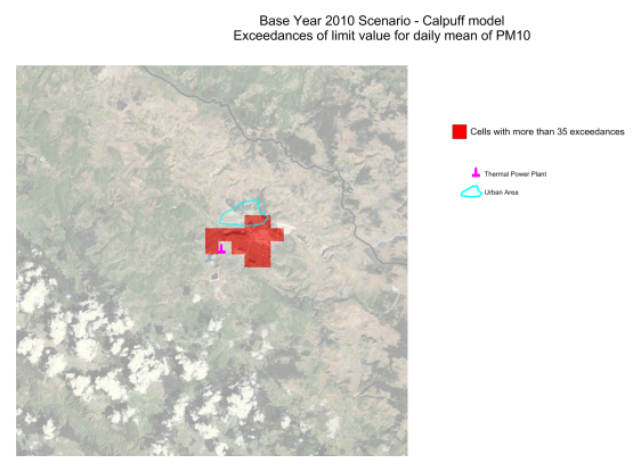

Figure 3: $\quad$ Area of exceedance of daily average of $\mathrm{PM}_{10}$ over Pljevlja in 2010.

\section{Reduction measures}

After identifying the main sources of pollution, a selection of possible measures to be adopted and implemented to reduce air emissions and improve ambient air quality was performed; the proposed measures were discussed with the policy makers in order to define a list of measures to be evaluated in terms of effectiveness. 
The proposed measures are divided into three groups: low cost technical measures having direct impact on emission levels and to be implemented in a short time, technical measures to be implemented as soon as additional financial resources will be available and finally additional measures, including non technical measures that can strengthen the effect of technical ones.

The coal mine is a primary source of particulate matter since it is an open mine and no particular abatement systems are implemented. Taking into account the limited amount of financial resources available for the implementation of the Plan, a list of low cost measures with a quite high reduction potential has been selected in order to start reducing diffuse emissions from mine activities. Selected measures in this sector are the followings: paving the surface of roads covered by trucks transporting coal with asphalt or gravel; reducing truck speed from $65 \mathrm{~km} / \mathrm{h}$ to $30 \mathrm{~km} / \mathrm{h}$, eventually strengthened by increasing distances between trucks; standard procedure for watering of roads; reduction or suspension of operations during dry, windy conditions and when measured $\mathrm{PM}_{10}$ concentration levels are high.

Regarding the thermo power plant, it is already planned by the company managing the plant to solve the efficiency problems with the electro filter recently introduced on the stack. Even if the impact of thermal power plant is not relevant on the territory of the urban area of Pljevlja it will be useful to reduce emission levels of the plant to improve general air quality of the area and reduce long range air pollution and the possible impact on neighbouring Countries.

As second level of implementation, being coal burning in boilers and stoves used for heating in residential and service sectors a main source of pollution for particulate matter and benzo(a)pyrene, the previously planned project on the new District heating system would greatly reduce air pollution from this sector. Substitution of the old district heating system and of individual boilers and stoves with a remote heating system using heat from the thermal power plant will have a great impact in terms of energy saving, economical advantages and environmental improvement. Of course it is a big project; therefore its application depends on the availability of financial resources.

At this level other measures on the coal mine can be represented by the enclosing of crushing plant and its fitting with water sprays. Road transport is also a relevant source of pollution for nitrogen dioxides. Suggested measures in this sectors are related to: substitution of old vehicles with less polluting ones; improvement of public transport introducing new low emissions public vehicles and increasing the service in order to reduce private traffic flows.

In Table 2 a potential reduction has been associated to the main technical measures in order to estimate their impact on the emission levels after the implementation [2, 7-10].

Finally, some non technical additional measures related to different sectors are: setting a regulation to stop urban and agricultural waste burning and improve inspections at local level; improving prevention against forest fires (through regulations, inspections and public information campaigns); organizing public information campaigns in order to raise awareness of the population of the 
consequences of personal choices and behaviours on the environment. These measures are not technical, therefore they do not have direct evaluable effects on the level of pollution; for this reason they were not evaluated in terms of their effects on the levels of emissions nor in terms of their impact on the air quality of the Municipality. They can be taken into account if additional financial resources will be available in order to increase the reduction potential of technical measures.

Table 2: $\quad$ Reduction potential of selected measures.

\begin{tabular}{|c|c|c|c|c|}
\hline Sector & Measure & Measure description & Pollutant & $\begin{array}{l}\text { Reduction } \\
\text { Potential }\end{array}$ \\
\hline \multirow{5}{*}{ Coal mine } & $\begin{array}{l}\text { Road } \\
\text { paving }\end{array}$ & $\begin{array}{l}\text { Paving of the surface of } \\
\text { roads covered by trucks }\end{array}$ & PM & $>90 \%$ \\
\hline & $\begin{array}{l}\text { Speed } \\
\text { reduction }\end{array}$ & $\begin{array}{l}\text { Reducing truck speed from } \\
65 \mathrm{k} / \mathrm{h} \text { to } 30 \mathrm{k} / \mathrm{h}\end{array}$ & PM & \multirow{3}{*}{$\begin{array}{l}50 \% \\
\text { (conserva- } \\
\text { tive } \\
\text { estimation) }\end{array}$} \\
\hline & Watering & $\begin{array}{l}\text { Watering (standard } \\
\text { procedure) }\end{array}$ & PM & \\
\hline & $\begin{array}{l}\text { Reduce } \\
\text { operations } \\
\text { in windy } \\
\text { days } \\
\end{array}$ & \multicolumn{2}{|c|}{$\begin{array}{l}\text { Reduction or suspension of } \\
\text { operations during dry, windy PM } \\
\text { conditions }\end{array}$} & \\
\hline & $\begin{array}{l}\text { Closed } \\
\text { crushing }\end{array}$ & $\begin{array}{l}\text { Closure of crushing plant } \\
\text { and fitting with water sprays }\end{array}$ & PM & $85 \%$ \\
\hline $\begin{array}{l}\text { Thermo } \\
\text { power plant }\end{array}$ & $\begin{array}{l}\text { Electro- } \\
\text { filter }\end{array}$ & $\begin{array}{l}\text { Improvement and adjustment } \\
\text { of the electro filter to } \\
\text { obtained certified efficiency }\end{array}$ & PM & $99 \%$ \\
\hline $\begin{array}{l}\text { Domestic } \\
\text { and service } \\
\text { heating } \\
\text { systems }\end{array}$ & $\begin{array}{l}\text { TPP } \\
\text { District } \\
\text { heating } \\
\text { system }\end{array}$ & $\begin{array}{l}\text { Substitution of actual heating } \\
\text { systems in sector with } \\
\text { heating system using heat } \\
\text { from the TPP }\end{array}$ & $\begin{array}{l}\mathrm{PM} \text { NOx } \\
\mathrm{SOx} \\
\mathrm{BaP}\end{array}$ & $78 \%$ \\
\hline
\end{tabular}

* TPP - thermo power plant.

\section{Future emissions scenarios}

In order to assess the possible impact of reduction measures on the air quality status of the Municipality and therefore evaluate the effectiveness of the adopted strategy, two different future scenarios were produced with reference to 2020: Business As Usual (BAU) or Reference Scenario and Plan or Mitigation Scenario.

The air quality model previously applied to determine the present air quality status was implemented also in the Plan scenario that was performed in order to estimate pollutant concentrations following the implementation of reduction measures and check their effectiveness in producing the expected reduction of concentrations. 
The first step of activities was the creation of a Business As Usual (BAU) or Reference Scenario; this scenario considers all planned and approved measures, in order to respect air quality standards, taken at local and national level. In addition, this scenario contains all socio-economical and technological trend not related to measures strictly devoted to air quality, like gross domestic products, population, import-export of goods, etc. This Reference Scenario is used as a basis to which all alternative scenarios will be compared, in order to define additional measures for minimizing economic costs to obtain air quality goals that have been set.

The reference scenario was produced for the Municipality of Pljevlja taking into account 2010 as base year and applying the Projection module of $E^{2}$ Gov environment and energy model system $[11,12]$.

The following step was the creation of the Plan or Mitigation Scenario; it includes reduction measures directly related to air quality improvement. The main difference with the Reference Scenario is that the Mitigation Scenario must contain measures that will affect emissions in order to fully comply with air quality standards, often counterbalancing Reference Scenario trends that will produce a rise in emissions.

The production of baseline and plan scenarios was carried out through the following phases:

- information retrieval of current legislation on relevant environmental issues;

- collection of available documentation on planned policies and strategies on the main sectors (energy, industry, agriculture, waste); collection of data on general macro-indicators and evaluation of any possible reduction measures;

- modelling application of Projection to obtain emission scenarios;

- production of maps and tables describing the obtained results.

In order to produce the Reference scenario, the following documentation was taken into account:

- National Spatial Plan of the Republic of Montenegro until 2020 - Ministry of Environmental Protection and Physical Planning, August 2006;

- National Strategy of Sustainable Development of Montenegro - Ministry of Tourism and Environmental Protection, January 2007;

- Energy Development Strategy of the Republic of Montenegro by 2025 Ministry for Economic Development of the Republic of Montenegro, June 2007;

- Agriculture and Rural Development Strategy - Ministry of Agriculture, Forestry and Water Management, July 2006;

- UNFCCC First National Communication - Ministry for Spatial Planning and Environment of Montenegro and UNDP Montenegro, November 2009.

Trend of activities can be evaluated for different forecast scenarios, for example for Low, Mid and High trend. Taking into account the situation of the Country, global crisis and the average statistical indexes at international level, the present study takes into account only a low growth hypothesis.

Future emissions scenario was produced using 2010 as a base year and 2020 as final year for all relevant pollutants. Main parameters used to make emissions forecast are related to the following issues: population; GDP; energy needs for 
different sectors; evolution of air and road transport; a planned second group of the thermal power plant.

According to the planned evolution of activities, total emissions are expected to grow in the next ten years. Results of estimated emission in 2020 are reported in Table 3.

It is clear that total emissions of all analysed pollutants are going to increase in the following years, if no reduction measures are implemented. Nitrogen oxides emissions grow for the $28 \%$ and sulphur oxides emissions for the $20 \%$, while particulate matter emissions increase for more than $300 \%$. The natural growth of emissions due to the increase of population and consequently of energy consumption (mainly for transport and heating) is accompanied by a high increase due to the introduction of the second group of the thermal power plant.

It can be therefore concluded that the adoption and implementation of reduction measures is necessary in order to avoid a worsening of ambient air quality in the Municipality of Pljevlja.

Plan scenario was produced applying the same methodology used for the Reference scenario. In this case, reduction potential of the selected measures was introduced in the model to estimate the effect of measures on the total level of emissions. The applied reduction potential is that indicated in for each measure or group of measures having an impact on the coal mine, thermal power plant and heating systems. Obtained results are shown in Table 3.

Table 3: $\quad$ Forecasted 2020 emissions in Plan scenario.

\begin{tabular}{lrrrr}
\hline Scenario & \multicolumn{4}{c}{ Pollutant total emissions $(\mathrm{Mg})$} \\
& $\mathrm{NO}_{\mathrm{x}}$ & $\mathrm{PM}_{10}$ & $\mathrm{PM}_{2.5}$ & $\mathrm{SO}_{\mathrm{x}}$ \\
\hline 2010 Inventory & 4378.15 & 1975.64 & 549.01 & 25974.72 \\
2020 Reference scenario & 5617.9 & 8010.87 & 2298.31 & 31204.05 \\
2020 Plan scenario & 4747.47 & 576.61 & 239.45 & 26091.03 \\
\hline
\end{tabular}

Analysing the previous table, the selected measures obtained a balance on the rise of emissions caused by the introduction of the second group of the thermal power plant and produced a sensible reduction of the total level of emissions of all pollutants. The effect is more relevant on particulate matter, since this pollutant was selected as a priority; all selected measures have an impact on its levels, while the only action on other pollutants is that of heating systems. Selected measures have a relevant impact on PM emissions, reducing them at lower levels than those estimated for the Reference scenario, but also than those evaluated for the base year (2010 inventory).

Next paragraph describes the results of the investigation on how these emission reductions impact on the air quality in term of concentrations of $\mathrm{PM}_{10}$ and $\mathrm{PM}_{2.5}$. 


\section{Future air quality scenarios}

The forecasted emissions in Plan scenario have been used as input data for the dispersion model CALPUFF in order to find out direct impact of the aforementioned measures on air quality at local level.

The annual mean concentrations of investigated pollutants, as estimated through the application of CALPUFF model, are shown in Figure 4 that represents the distribution of mean annual concentration of sulphur dioxide, nitrogen dioxide and particulate matter $\left(\mathrm{PM}_{10}\right.$ and $\left.\mathrm{PM}_{2.5}\right)$ over the territory of Pljevlja and reports the overall maximum evaluated concentrations. The location of thermal power plant and the outline of urban area are also indicated.
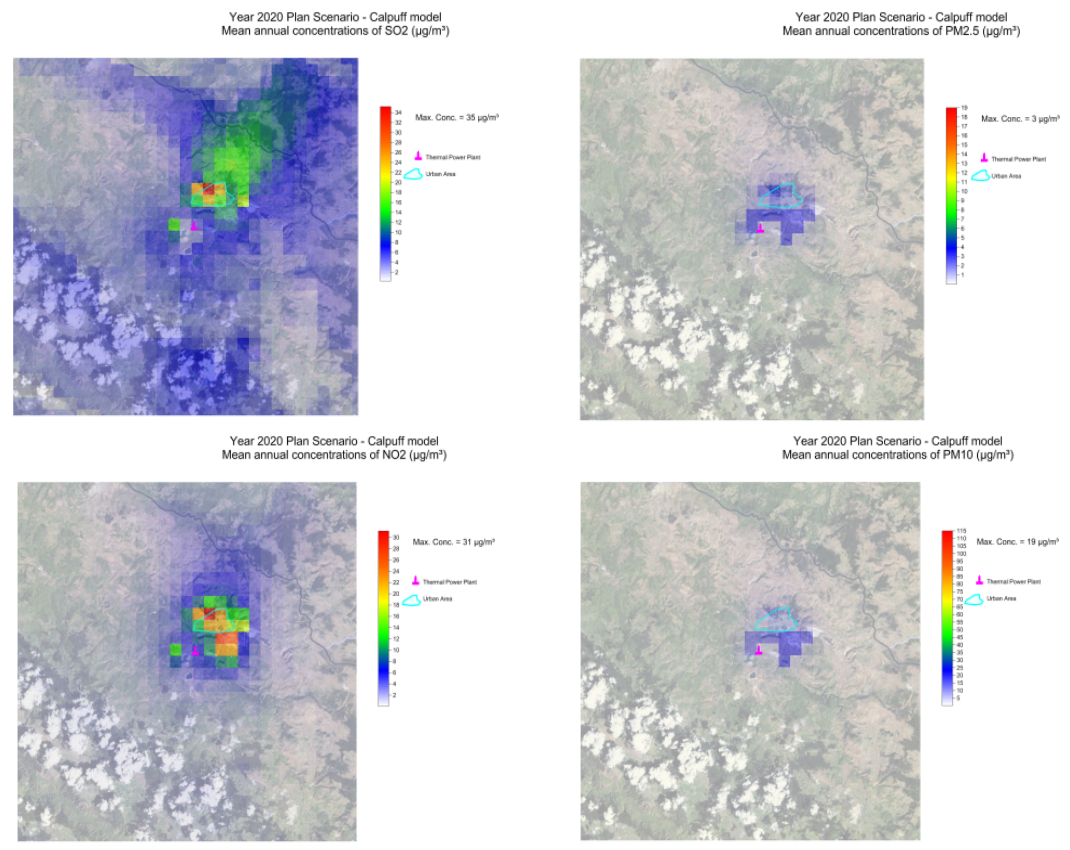

Figure 4: Annual 2020 average concentrations of pollutants in Plan scenario.

Analysing the previous maps the following considerations can be drawn:

- estimated concentrations of $\mathrm{SO}_{2}$ and $\mathrm{NO}_{2}$ do not change since adopted reduction measures are focused on the reduction of particulate matter levels; a really low increase is registered due to the increase of emissions evaluated in the Business as usual scenario;

- estimated concentrations of $\mathrm{PM}_{10}$ and $\mathrm{PM}_{2.5}$ are much lower than those registered in 2010;

- the annual average of $\mathrm{PM}_{10}$, for which an exceedance of the limit value was registered in 2010, is in compliance with the air quality standard in 2020; 
- the exceedance situation registered in 2010 for the daily limit value of $\mathrm{PM}_{10}$ is no longer detected: there are no grids for which the model estimates exceedances of the limit value in 2020 plan scenario.

\section{Conclusions}

The paper reports a complete air quality study for the area of Pljevlja in Montenegro, using emission inventory, projection techniques and meteorological (MM5 and CALMET) and air quality (CALPUFF) models. The study shows the proposed measures allow the compliance with the air quality standards set for the annual and daily average of $\mathrm{PM}_{10}$ for which exceedances of the limit values were registered in 2010 .

\section{Acknowledgements}

The study was carried out in the frame of cooperation between the Government of the Italian Republic and the Government of Montenegro for Environmental Protection.

\section{References}

[1] EMEP/EEA, Air pollutant emission inventory guidebook 2013, EEA European Environment Agency, draft.

[2] United States Environmental Protection Agency, Compilation of air pollutant emission factors. Volume 1. Stationary point and area sources. Fifth edition. EPA report AP-42. North Carolina, U.S.A.

[3] Scire J.S., Yamartino R.J., Strimaitis D.G., A user's guide for the CALPUFF dispersion model, TRC Companies .

[4] Jelena Knezević (2012), Master Thesis "The Analyzes of the air polluting emissions from the thermal power plant in Pljevlja to the air quality by applying Mathematical CALPUFF Model" ("Analiza uticaja zagađivača vazduha iz Termoelektrane u Pljevljima na kvalitet vazduha primjenom matematickog CALPUFF modela”), September 2012, Podgorica, University of Montenegro, Faculty of Metallurgy and Technology.

[5] Dudhia J., Gill D., Manning K.: PSU/NCAR Mesoscale Modeling System Tutorial Class Notes and User's Guide MM5 Modeling System Version 3.

[6] Scire J.S., Insley E.M., Yamartino R.J., and Fernau M.E.: A User's Guide for the CALMET Meteorological Model, TRC Companies.

[7] Bohn, R., Cuscinio, T., Cowherd, C., Fugitive Emissions from Integrated Iron and Steel Plants, EPA Report No. EPA-600/2-78-050, 1978.

[8] Foley, G., Cropley, S., Giummarra, G., Road Dust Control Techniques Evaluation of Chemical Dust Suppressants. Performance. Special Report 54 to ARRB Transport Research Limited, Australia, 1996.

[9] Midwest Research Institute, Background Document for Revisions to Fine Fraction Ratios used for AP-42 Fugitive Dust Emission Factors, MRI 
Project No. 110397, Western Governors' Association, Western Regional Air Partnership (WRAP) 2006.

[10] Australian Government, Department of Sustainability Environment Population and Communities, National Pollutant Inventory (NPI), “Emission Estimation Technique Manual for Mining” (EETM).

[11] Trozzi C., Vaccaro R., Piscitello E., Ruggiero A., Integrate Emission Inventory in Environmental Governance Information Systems, U.S. Environmental Protection Agency 18th International Emission Inventory Conference, Baltimore, April 14-17, 2009.

[12] Leonardi C., Trozzi C., Piscitello E., E2 Gov Environment and Energy System, Regional Air Emissions workshop to support West Balkan Countries in setting up national level reporting of AE, Bar, Montenegro, 24-25 November 2011. 